\title{
Authorial and Narrative Voice in the Heptaméron
}

\author{
DEBORAH N. LOSSE
}

Countless literary historians have set out to identify the authorial voice in the Heptaméron with one of the devisants. ${ }^{1}$ To embark on such a search is of course to risk negating the diegetic authority of the other nine story-tellers and to forget that Marguerite de Navarre is, after all, the creative force behind all of the devisants. ${ }^{2}$

How then is the reader to react to the polyphony of meanings resulting from the various narrative levels? ${ }^{3}$ Can one distinguish the authorial voice from the plurality of narrative voices? Should one attribute the same diegetic authority to all the narrative voices present in diegetic (frame) and metadiegetic (inscribed tales) levels of the text? What is the relationship of the events and discourse of the frame to the same elements in the tales? And finally, to quote Mary Jacobus, "is there a woman in [the] text?"4 These questions are central to the dynamic structure of the Heptaméron.

In The Narrative Act, Susan Sniader Lanser provides a model for probing some of these questions and for evaluating the various narrative levels and levels of authority in the text. To begin with, one voice presents itself to the reader - the textual voice, shaped by the conventions of language which in turn reflect the values of the community. ${ }^{5}$

The first component of textual voice confronting the reader as he or she picks up a work and opens the cover is the extrafictional authorial voice "whose presence accounts, for example, for organizing, titling, and introducing the fictional work" (Lanser, p. 122).

In the case of the Heptaméron, the critical reader has a minimum of extrafictional material with which to reconstruct the surface elements of the extrafictional voice. All the editions, with the exception of the incomplete and oddly assembled first edition of Pierre Boaistuau (1558), attribute the work, variously entitled L'Heptaméron des Nouvelles, Contes et nouvelles, Les Nouvelles to Marguerite de Valois, Reyne/reine de Navarre. At a time when the expected norm was certainly male authorship, it is significant that her name appeared in open, undisguised form on the title page, a factor whose effect on the reader, Renaissance or modern, will be discussed 
below. The modern reader who uses the edition of Michel François finds only the name of the author and the title on the title page. Just the word L'Heptaméron appears without reference to the genre to which the work belongs. For the Renaissance reader, the extrafictional voice sets expectations of genre by mentioning nouvelles in the title. Furthermore, explicit mention of Marguerite's family, the Valois, could only have increased the diegetic authority of the author in terms of her proximity to the royal court, whose events she recounts within the primary (diegetic) and secondary (metadiegetic) levels of the work. Qualificative adjectives, "trés illustre et trés excellente," appearing in the Claude Gruget edition of 1559 and reproduced repeatedlythroughout the sixteenth century, only serve to enhance the authority of the extrafictional voice. ${ }^{6}$

A paucity of other explicit signs of the extrafictional voice-epigraphs, chapter titles, postface - leads the reader to infer a degree of self-effacement on the part of the authorial voice, an inference that will be reinforced by the restraint of the primary narrative voice. Yet even the few bits of information incite the reader to begin constructing an image of the textuallyencoded author?

In the Heptaméron, the prologue functions as the entry into the diegetic narrative world, the frame story or first narrative level as defined by Genette and further elucidated by Bal. ${ }^{8}$ It is here that our analysis of the narrative voice begins. In formulating her poetics of point of view, Lanser examines the voice of the public narrator and the voice of the private narrator, as well as the voices of the focalizers, characters through whom the narrative events are viewed, from the standpoint of status, contact, and stance.

Chief among the concerns of status in the instance of the public narrator, as judged by the reader, are the questions of authorial equivalence, representation of voice, privilege, reference, and social identity (Lanser, pp.147174). The public narrator narrates directly to the extrafictional audience at the primary narrative level. Since the question of social identity (gender, race, class) affects the other concerns, let us begin by considering the effect of gender on the diegetic authority of the public narrator in the Heptaméron.

Lanser posits, and I think rightly so, that the "unmarked case" for writing and narration is the male voice. An anonymous work or a work designated with only the initials of the author will be presumed to have been written by a male, unless otherwise indicated. Since even the most naive reader brings his or her cultural values and expectations to the reading process, the "noted presence" of a female extrafictional voice perceived on the title page necessarily affects the reader's reception and processing of the text (Lanser. p.167). Furthermore, once the reader has noted the female extrafictional voice, unless there are signs to the contrary, he or she will 
assign a female gender to the narrative voice. While nothing prevents the woman author from assuming a male narrative voice, "the convential case is one of homogeneity between the extrafictional and the public narrative voice."

There is a strong argument for equating the public narrator with the textual author in the Heptaméron. No distinct identifier separates the two, nor is the public narrator "fleshed out" in the manner of Alcofrybas Nasier in Rabelais's work.

If we attribute the social stature of the extrafictional voice to the public narrator of the Heptaméron, a female member of Frances royal family, there is a corresponding effect on two elements of narrative status. The reader is more likely to believe the narrator's claim for historical accuracy, for she has been admirably placed to record the actions of the noble men and women who make up the cast of characters. ${ }^{9}$ One is apt to credither with a heightened diegetic authority - based on her closeness to the events she is recording - as well as with an enhanced mimetic authority, for her stature inspires a feeling of honesty, reliability, and competence in the reader.

The final question of narrative status involves representation and privilege. Homodiegesis refers to a narrative in which the narrator is involved as a character. Heterodiegesis concerns an act of narration in which the narrator is outside the story world. ${ }^{10}$ Although Marguerite's public narrator recounts the prologue in the first person: "Ma fin n'est de vous declarer la scituation ne la vertu desdits baings, mais seullement de racompter ce qui sert A la matiere que je veulx escripre" (Heptaméron, p.1), she is not a character in the story. The privilege of the public narrator is one of omniscience. Not involved as actant in the story, she has access to the characters thoughts and feelings.

The second determinant of narrative voice concerns the modes of contact between narrative voice and audience. Building on the distinction between covert and overt narrative techniques outlined by Seymour Chatman, Lanser establishes a series of axes along which elements of narrative contact are to be evaluated (Lanser, pp.174-182):

direct

overt

narrative

self-

consciousness

confidence

deference

formality indirect

covert

narrative

unconsciousness

uncertainty

contempt

informality 
The public narrator of the Heptaméron lies somewhere to the right of the extreme pole of overt narration. The extreme pole represents the constant dialogue between narrator and audience characteristic of the prologues of Rabelais or the tales of Bonaventure Des Périers. ${ }^{11}$ The public narrator of the Heptaméron uses restraint in evoking the reader's presence in the prologue, but she addresses herself directly to her inscribed readers or narratees on several occasions: once as she explains her objective (p.1, cited above), farther on to introduce the devisants (p.3), and again at the conclusion of the prologue to assure the inscribed reader of the beauty of the setting, the meadow where the stories will be recounted (p.10).

The narrative techniques used in the prologue are not entirely typical of those used by public and private narrators in the rest of the work. The bulk of the prologue consists of a summary of events, subsequent to the action. The summary of story events is characteristic of overt narration. ${ }^{12}$ The narrator does recreate thedialogue between devisants, but summary far exceeds dialogue in the prologue.

When the public narrator returns at the end of each tale to transmit the discussion to the extrafictional audience, she recreates the conversations in direct, tagged speech, and thus gives the appearance of faithfully transmitting the dialogue. Instances of indirect discourse, where the public narrator reports the words of the devisants, are rare. She intervenes infrequently to add a note of clarification or transition. There is virtually no difference between the story time and the time of narration in the conversations framing the tales. The public narrator only reverts to summary at the end of each day to recount how the story tellers pass the evening.

As a consequence of the gradual diminishment of direct narrative contact with the public or primary narrator, the implied reader has very scant information with which to build up the narrator's image. It is present in the text but so restrained as to inhibit the process of "rounding out." In contrast, the frequent "prise de parole" by the private narrators or devisants, both as second-degree narrators at the metadiegetic level and actants at the diegetic level, facilitates the process of constructing an image of each story teller.

Other considerations concerning the modes of contact between the narrator and audience involve the degree of narrative selfconsciousness, confidence, deference, and familiarity with the implied reader. Much as in the Thousand and One Nights, the public and private narrators of the Heptaméron are deeply conscious of the narrative process. Narration is perceived as a means of preserving good health and recovering from the human losses of the flood. Parlamente urges Dame Oisille to propose a means of biding their time lest they remain "en dangier de demeurer malade" (p.7). Worse still, Longarine adds, they may remain depressed by the events: "fascheuses, qui est maladie incurable." Without some light- 
hearted diversion, Ennasuite assures them, they will not survive the morrow: "... nous serions mortes le lendemain."

The concept of narration as a life-giving force is central to the structure of the work. Not presented as an isolated notion. the homology of storytelling and life receives reinforcement by various voices and forms the basis for narrative activity in the Heptaméron ${ }^{13}$ References to the positive effects of narration recur throughout the work but are not highlighted to the same extent as in the prologue. ${ }^{14}$

The narrator s posture of narrating, confident as opposed to uncertain, has its roots in the salutory function of the narrative act. The public narrator's deliberate, straightforward tone reinforces the characters' avowed confidence in storytelling. As the primary narrative voice approaches the implied reader with a degree of polite deference, it establishes a degree of relative equality between speaker and listener. It is a voice that is neither extremely formal nor excessively intimate.

There corresponds to the public narrator a public narratee, "atextual construct of the audience or readership"(Lanser, p.179). Indications of the "particularizing social and physical aspects" of the public narratee are scarce in the Heptaméron.$^{15}$ Reference to Boccaccio, made directly to the public narratee and not to the secondary narratees, the storytellers, indicates that the narratee is familiar with Boccaccio, and consequently, slightly above the degree zero narratee defined by Prince and Powowarczyk as unaware of other texts. Only the refined style of the public narrator would lead us to deduce that the social milieu of the narratee was the same as that of the devisants. The scant reference to an audience in a totally undefined spatial-temporal location suggests that we are dealing with a degree zero narratee.

Stance, or the speaker's relationship to the message, is the last of the three categories to be analyzed in the evaluation of the public narrator (Lanser, p. 92). Stance can be viewed along four different planes: the phraseological, the spatio-temporal, the psychological, and the ideological, of which Lanser views the last two to be the most significant (Lanser, p. 184). ${ }^{16}$ Because of the greater visibility of the private or secondary narrators in the work itself and the filtering of the public narrator's stance through the intermediary of the devisants, we shall first view stance from the point of view of the secondary narrators, and then try to draw some conclusions about the primary narrative stance.

The dual role of the storytellers as both narrators and actants makes it possible for them to be individualized and to take an active role in the narration and the reception of the metadiegetic discourse. Their distance from the extrafictional voice and their individualized status necessarily subordinates their diegetic authority to that of the public narrator, but their mimetic authority - proximity to the events they are narrating, reliability, 
and competence as narrators - is equal to that of the public narrator. Like her, they are direct, overt narrators whose narrative audience, made up of other storytellers, is far more involved in constructing the textual meaning.

A significant cause for ambiguity in reconstructing the textual voice of the Heptaméron, and from there the authorial voice. comes from the divergent narrative voices in the text. Let us view the four planes determining the stance of private narrators in the hopes of defining convergence and divergence of first- and secondlevel narrative voice.

The first plane concerns the phraseological plane or what Genette refers to as mode du récit or discursive mood. ${ }^{17}$ Marguerite's narrators use all the moods available to them on the spectrum, from "pure narration" (diegesis) at one pole, where all speech is filtered through the voice of the narrator. to dialogue (mimesis), where the words are uttered by the characters without narrative intervention. ${ }^{18}$ As I have pointed out in another study, Marguerite draws upon narration, psychonarration, indirect discourse, interior monologue, direct speech, and written letters to a far greater extent than her contemporary Bonaventure Des Périers, who generally restricts himself to narrated discourse, indirect and direct speech (dialogue).${ }^{19} \mathrm{In}$ the interest ofrecreating psychological struggle, the narrative voice in the Heptaméron blends with the voice of the character in psychonarration, where the narrator remains effaced while reporting the words and thoughts of the characters, or fades away entirely so that the character can speak or relate his or her inner thoughts. ${ }^{20}$

To see how the narrator combines moods, let us examine the twentythird tale, the story of the Franciscan who, after warning the gentleman in whose home he is a guest that it is too soon to resume conjugal relations with his wife, enters the wife's chamber and sleeps with her. The tale begins with the omniscient, extradiegetic narrator, Oisille, relating the events: the gentleman's blind faith in Franciscan virtue, the birth of the child, and how the birth has strengthened the love of the couple. As if to emphasize the gentleman's naive faith in the Franciscans, the narrator yields the floor to him when he asks in direct, tagged speech if it is a sin to sleep with his wife so soon after childbirth. The priest responds in direct, tagged speech that it is indeed a grave sin, but the narrator introduces the dialogue with an ironic portrait of the "beau pere, qui avoit la contenance et la parolle toute contraire A son cueur" (p.187). Other ironic epithets, the word "frater" applied as he is burning with desire for the wife, are reminders of the presence of a biased narrator rather hostile to religious hypocrisy. Dramatic moments of the récit a re rendered in direct speech: the chiding words of the woman to the monk whom she presumes to be her husband and the words exchanged between husband and wife when they discover the monk's ruse. Indirect speech and narrated speech help advance the plot, but it is the use of psychonarration - the fusion of narrative voice with the consciousness 
of the character - which renders the despair of the new mother most immediate. The reader is conscious of the narrative presence but perceives also the words and mind of the persona:

La damoyselle demeura seulle en son lict, n’ayant auprés d'elle conseil ne consolation, que son petit enfant de nouveau né. Considerant le cas horrible et merveilleux qui luy estoit advenu, sans excuser son ignorance, se reputa comme coulpable et la plus malheureuse du monde. (p.190)

The effacement of the narrator is such that one perceives the words "horrible," "merveilleux," and "la plus malheureuse du monde" to be the perceptions of the young women rather than those of a mediating narrator.

Dorrit Cohn believes that there are times when psychonarration, although not as close to the mimetic pole of the spectrum as to the diegetic, is more effective than direct or indirect discourse in terms of the narrator's superior knowledge of the character's inner life and his or her superior ability to present and assess the character's state of mind. ${ }^{21}$ The example of Oisille's discreet mediation of the young woman's despair illustrates theimpact of psychonarration on the reader.

In a single tale, we have seen how the narrative voice changes from omniscient and ironic, a stance that creates distance between the monk and the reader, to subtle and effaced, allowing the reader to have access to the immediacy of the mother's grief. The dynamics of the narrative voice lie in the rapid shifts from one mood to another, as when the narrator cuts short the above passage involving psychonarration to point out the deficiencies inherent in Franciscan teaching:

Et alors, elle, qui n'avoit jamais aprins des Cordeliers, sinon la confiance des bonnes oeuvres, la satisfaction des pechez par austerité de vie, jeusnes et disciplines, qui du tout ignorait la grace donnée par nostre bon Dieu par le merite de son Filz, la remiss on des pechez par son sang..., se trouva si troublée ... qu'elle estima la mort trop plus heureuse que sa vie. (pp.190191)

Here, the rapid enumeration of theological concepts is not within the grasp of the young mother, as the narrator tells us, and so represents the intrusion of a narrator whose concern for doctrine and false doctrine is evident throughout the work.

The discussion of phraseological stance brings us close to the spatial and temporal stance of the narrator. Perhaps because of the brevity characteristic of the genre, the narrator's spatial stance limits itself in general to the midpoint on the spectrum of possibilities. The narrator's stance begins from outside the tale, where there is a brief reference to geographic location and some mention of the social standing and family connections of the protagonists. Not really the detailed panoramic overview characteristic 


\section{0 / Renaissance and Reformation}

of the nineteenth-century French novel, the situating of the tale does serve as an overview permitting a glimpse of character traits, past or present. ${ }^{22}$ Once the narrative action begins, the narrative voice approaches the scene and occupies a "free, wandering ordination" enabling him or her to move freely about the scene. As the narrative tension builds in scenes of physical or psychological conflict, the narrator's spatial stance assumes successively the ordination of the characters in conflict. This last stance, shifting from character to character, allows the narrator to reveal the thoughts and perceptions of the personae. Located at mid-spectrum, free, these two stances, free, wandering and shifting, do not limit the spatial ordination in the manner of a stance fixed on a single character. Marguerite does not make use of fixed ordination.

The seventy-first tale provides a lively example of shifting ordination. A husband whose wife is dying seeks consolation at the side of his maid. The narrative voice assumes first the husband's ordination as he addresses the maid: "M'amye.... Regarde comme j'ay le visaige froid, approche tes joues des myennes, pour les me rechaulfer" (p.423). The narrator shifts from the man's stance, as he caresses the maid, to the maid's stance as she begins to feeluneasy: “. . . il luy mist la main au tetin, dont elle cuyda faire quelque difficulté... " A third shift occurs as the narrator assumes the spatial ordination of the man's dying wife, "qui n'a voit compaignye que de la croix et l'eau benoiste, ... commencea, avecq sa faible voix, de crier le plus hault qu'elle peut: 'Ha!ha!ha! je ne suis pas encore morte!'” The rapid shifting, combined with the narrator's ironic commentary about the holy water, produces a dynamic quality which the situation alone could not provide.

As for temporal stance, both primary and secondary narrators' insistence on the historicity of their narrative enterprise precludes variation from the posterior view. While we may assume that the narrating instance of the frame is less remote than that of the second-level narration, the narrative voice clearly and repeatedly encourages the reader to grant greater diegetic authority to the devisants in view of the fact that they are narrating "veritables histoires." A degree of remoteness between narrated event and narrating instance results from the overemphasis of historical referentiality.

The secondary narrators, in contrast to the primary narrator, are able to offset this remoteness by recreating the most important narrative events in scenes instead of summary. By creating a semblance of equality between the duration of the narrative event and the narrating instance, the event seems more immediate. ${ }^{23}$ This is not to say that summary - where the duration of the narrated event far exceeds that of the telling - does not exist on the secondary level of narration, but the moments of crisis are depicted in scenes where direct discourse and scenic notation slow down the narrative pace. 
The temporal element of duration may serve to reveal the psychological or ideological stance of the narrator. We need only consider the scenes in which feminine courage is pitted against male aggression. The tale of Soeur Marie Heroet (Tale 22) and the tale of the ferrywoman (Tale 5), the tale of the bourgeoise FranÇoyse, who refuses to give in to the advances of a nobleman (Tale 42), all incorporate scenes in which the woman speaks up in direct discourse to defend her virtue. The narrators turn to scenes to reenact the quarrels between abusive figures of power and their subordinates. The story of Rolandine (Tale 21) and the story of the assassination of the Duke of Florence(Tale 12) include scenes where the eloquence of the wronged subordinate contrasts the angry, self-serving posture of the superior.

An analysis of psychological stance of the narrator reveals his or her attachment to the individual characters, whether or not they are viewed from within or from without, how deeply the narrator probes their consciousness, and whether or not the narrator approves of them. Within the first-level narration, including frame story and commentaries, there is marked evidence of gender bias. Simontault introduces the first tale by proclaiming the unkind treatment he has suffered from women:

Mes dames, j’ay esté si mal recompensé de mes longs services, que pour me venger d'amour et de celle quim'est si cruelle, je mectray peine de faire ung recueil de tous les mauvais tours que les femmes ont faict aux pauvres hommes, et si ne diray rien que pure verité.

(p.11)

Hircan openly sides with the male characters even in tales where the behavior of the male character is reprehensible. Parlamente laments the lack of virtuous males: “. . mais estre homme de bien envers les dames, garder leur honneur et conscience, je croy que de ce temps ne s'en trouveroit point jusques A ung"(p.260). When Hircan offers a story depicting the "bons sens d'un mary et la fragilité d'une femme" (pp.259-260), Longarine counters with a tale portraying male weakness: "Si est-ce que, suyvant la fragilité des hommes qui s'ennuyent de manger bon pain, il fut amoureux d'une mestayere qu'il avoit" (p.270).

From the perspective of literary history, the reader may interpret the tension between male and female as an echo of the intertextual world of the "Querelle des Femmes." From the point of view of narrative, the psychological stance of the narrator, his or her affinity for one character and distance from another, shapes the depiction of characters and the narration of events. To determine how gender affects psychological stance, let us compare two tales, Tales 38 and 39 , both recounting a woman's reaction to her husband's infidelity. Dagoucin and Longarine set out to praise feminine virtue, defined as "la patience de vertu" (p.266). We shall examine both, the first narrated by Dagoucin and the second by Longarine, in the 
light of the narrator's involvement: how much information is provided about each character, how the characters are viewed, and whether or not they meet with the narrator's approval. ${ }^{24}$

Both tales begin with a flattering portrait of the wife. Dagoucin describes Madame de Loué as "tant saige et vertueuse qu'elle estoit aymée et estimée de tous ses voisins"(p.266) Longarine speaks of the bourgeoise de Tours as "une bourgeoise belle et honneste, laquelle pour ses vertuz estoit non seullement aymée, mais craincte et estimée de son mary" (p.270). Events and characters are viewed from the narrator s perspective in nonfocalized narration with occasional moments of variable, internal focalization, where the reader perceives the action or situation from the point of view of one of the characters. ${ }^{25}$

Having praised Madame de Loué, Dagoucin shifts the emphasis to the activities of the husband: how he has entrusted the management of financial and material affairs to the wife and how things have prospered. While ostensibly the agent of their good fortune, Madam de Loué loses textual visibility to her husband's initiative:

\begin{abstract}
Ayant vescu ainsy longuement avecy son mary, duquel elle porta plusieurs beaulx enfans, la felicité, A laquelle succede tousjours son contraire, commencea A se diminuer, pource que son mary, trouvant l'honneste repos insupportable, l'abandonna pour chercher sontravail. Et print une coustume, que aussy tost que sa femme estoit endormye, se levoit d'auprés d'elle et ne retournoit qu'il ne fust prés du matin. (p.266)
\end{abstract}

The syntax of the sentence, of which the wife is the unnamed subject, reduces her to the status of object or patient, effected by her husband's stressed initiative. Up to this point in the narration of feminine virtue, we know as much about the husband as about the wife.

The narrator's inclination to cast the wife in a passive role continues as he recounts her reaction to the husband's infidelity. Jealousy consumes her to the point that she neglects household affairs, her family, and her own person. Detail after detail stresses her negligence and inability to cope with the loss of her husband's love. At this point, a more sympathetic narrator might choose to probe her feelings, to provide an analysis of what Lanser refers to as "preverbalized processes": thoughts and unexpressed perceptions. The narrator does not communicate her thoughts, and so we get no more than a surface vision of her limited to her actions. Only a kind word from a relation succeeds in turning her from negligence to action for the sake of her children.

The narrator falls short of his goal of praising feminine patience for several reasons. To begin with, her efforts to correct her husband's behavior are rather curious. In her first attempt-doubtless too indirect to hit home she presents him with a washbasin to cleanse himself. The second effort is 
direct in the extreme. As she sets fire to his bed, she speaks up in direct, unmediated speech for the first time in the tale: "Au feu! Au feu!" Her desire to harm her husband is contradicted by her efforts to warn him in time to flee the fire.

The narrator's portrait of the wife and her attempts to reform her husband fail to inspire admiration. The absence of subjective elements of approval, empathy, or pity suggests a certain distance between the narrator Dagoucin and the woman whose praises he has vowed to sing. With the exception of her final speech, in which she attempts to justify her actions, she remains mute. Dagoucin reports her actions and few words. By placing himself between the reader and the character, he creates a filter through which passes a minimum of information in no way sufficient to convince the reader of the wisdom or efficacy of her actions.

The husband continues to play an equal role in the narrating instance. The narrator applies some negative epithets to the husband; he is described as "honteux et marry," but Dagoucin refrains from overtly denouncing the man"s behavior. The words "sale" and "orde" are reserved for the maid. In the end, the husband, "bien ayse d'en eschapper A si bon compte," enjoys the happiness that the woman's long-suffering has made possible.

At the conclusion of the tale, Dagoucin could choose to praise the woman, but instead he speaks of the value of winning the husband's affection "par patience et longue attente." The women devisants reproach the narrator's bias in failing to show thehusband unworthy of the woman's efforts at reform. The women agree that a husband must merit the patient longsuffering of his wife. Their conclusion represents an absence, a missing element, in the original narration. Hircan's statement that women abandon their love at the first misstep of their mate fails to repair Dagoucin's omission, for the husband's adultery in the tale is repeated over a long period.

Longarine's portrait of the bourgeoise of Tours presents from the start a deeper vision of the woman's qualities. While the tale is shorter, the quantity of information provided about her physical and moral qualities, her thoughts and deeds, creates a more rounded portrait and suggests a greater affinity between the narrator and the character she is describing. The fact that the narrator follows closely the thoughts and actions of the woman accounts for the greater depth of vision. We see the woman's concern for the health of her husband when he returns cold and sniffling from his mistress's house. The wife takes pity on the miserable surroundings of the mistress and sends for furnishings to brighten the interior of the bedroom.

The wife is clearly the initiator, the agent of the narrative action, and the husband the receiver. Even when the focus of narration shifts to the husband, he is portrayed as the recipient of his wife's generosity, and her generosity overshadows his portrait: 
Luy [le mari], voiant la grande bonté de sa femme, que, pour tant de mauvais tours qu'il luy avoit faicts, lui rendoit tant de biens, estimant sa faulte aussy grande que l'honneste tour que sa femme luy avoit faict; et après avoir donné argent $\mathbf{A}$ sa mestayere, ... s'en retourna $\mathbf{A}$ sa femme, $\mathbf{A}$ laquelle il confessa la debte. (p.27l)

The narrator's overt expression of approval for the woman's action, stated above, only reinforces the affinity between narrator and protagonist perceived by the reader and evident in the quantity of character indices, thoughts, and actions recounted by the narrator. In the previous tale, narrated by Dagoucin, the narrator's affinity for the female character is less apparent, since he tells us as much about the husband as about the wife. His concern is the mutual happiness of the couple rather than the virtuous action of the wife.

The above analysis serves to illustrate just how an aspect of status, in this case gender, may affect the narrator's psychological stance and inform the narrative process. Gender need not impede the development of a deep affinity between a male narrator and a female protagonist. Geburon's dynamic portrait of Soeur Marie Heroet, in which he offers a deep vision of her thoughts, feelings, and actions, provides a succession of passages where she not only speaks up but reduces the lecherous priest to speechlessness by her strength and wit. His portrait of the ferrywoman is another example of his affinity with a female character.

The affinity of narrators for characters along gender lines is best displayed along a spectrum. Parlamente, both by the nature ofthe stories she recounts and by her overt commentaries, occupies the pole of affinity for female characters. Hircan, whose stories and explicit commentaries show his affinity for male characters, occupies the other pole. Nomerfide and Geburon occupy the middle ground, since they are not only able to establish a rapport with protagonists of the opposite sex but are able to present a deep vision of these characters. Their mimetic authority is not diminished when they present a character of the other sex; they cross the boundaries of gender without falling into sexual stereotypes.
Affinity
Affinity
female male characters characters

\section{Parl. Long. Enna. Oisille Nomer. Geb. Dagou. Simon. Saff. Hir.}

The devisants have been distributed along the spectrum according to the types of characters they present, their narrative affinity to the male and female characters, their ability to portray these characters, and their explicit commentary in reaction to the tales told. 
The spectrum merely represents the general inclination of the narrators both in the act of narrating and in responding to the tales recounted. The success of their narration depends upon their flexibility as narrators. Each narrator presents at least one tale in which he or she assumes the point of view of a character of the opposite sex. Perhaps the most amusing instance of this capacity occurs in Hircan's tale of the maid who sets her master to sifting flour while she runs to warn her mistress of his adulterous intentions (Tale 69). His re-creation of the apprehension, thought, wit, and humour of the maid and her mistress reveals a deep affinity between the narrator and the female characters.

A discussion of the effect of gender on the psychological stance of the narrators leads us back to the realization that the extrafictional and primary narrative voices are female. The creative force behind the plurality of voices is a female voice capable of portraying the despair of a longsuffering suitor with the same depth and sensitivity as the disappointment of a woman whose lover has betrayed her trust.

Psychological stance, revealed in character portrayal and focalization, is not far removed from the last aspect of point of view to be examined here - ideological stance. Our analysis deals not with the particular content of the stance but rather with how the ideological content is incorporated in the text, what authority it carries, and whether it corresponds to the ideology of the authorial voice (Lanser, p.216).

It is possible to communicate an ideology to the reader explicitly in the surface structure of the text. Such facts or statements, what Todorov refers to as "faits signifiés," are immediately comprehended by the reader without interpretation. ${ }^{26}$ The dialogic structure of the commentaries in the Heptaméron lends itself to the expression of explicit commentary, but the plurality of voices, each one expressing a personal ideology, makes it difficult to piece the many explicit statements into a whole. At the moment of enunciation, the ideology is comprehended, but when it is contradicted by a second or third voice utterance by other characters, the reader must face the task of resolving the contradiction. Some ideologies remain explicit and unchallenged in the work. The values are reinforced at both the primary and secondary narrative levels: the value of sincere prayer, the need for healthy, humorous pastimes, distaste for clerical hypocrisy.

The reader is often forced to retrieve ideology embedded in the deep structure of the text. Such information, what Todorov calls "faits symbolisés," requires interpretation. ${ }^{27}$ In the fifth tale dealing with the Franciscans' attempt to take sexual advantage of the ferrywoman, the narrator's manipulation of discourse so that the woman speaks up for herself and the monks remain silent, with only the narrator to report their words, offers an example of embedded ideology. There is no need for the narrator to speak of the virtue of "celles qui ne scavent rien" (p.57), for the reader has already 
perceived the value of simple wisdom in the speech and actions of the ferrywoman.

Do we accept the plurality of opinion in the Heptameron as inevitably filled with contradiction, or is it possible to reconstruct a locus of reinforced ideologies constituting an authoritative textual voice? One might begin by examining the various ideologies of the text to see if they are isolated cases or reinforced i) by a polyphony of voices in the text or ii) by "repetition and emphasis of a single character's stance" (Lanser, pp.220-21). The authority of the voices articulating the same ideology plays a role in determining the importance of the ideology within the work. By virtue of its association with the extrafictional voice, an ideology carried by the public narrator providing we are dealing with a reliable narrator - will be associated with the authorial voice.

In the Heptaméron, we have already noted the straightforward character of the ideologies carried in the primary narrative: the curative effect of storytelling, the positive value of dignified pastimes, the value of simple, communal worship, the merits of recounting stories based on historical events. The ideologies are stated and repeated in the primary narrative and reiterated by nearly all of the devisants at one time or another. Oisille's own profession of faith and choice of pastime, reading the Bible, is presented as her personal ideology rather than that of the group. Concealed within the prologue are two character indices-authoritative because of their situation in the primary narrative-which alert the reader to an ideological stance to be further developed in the second-level narration. The public narrator states explicitly and without qualification that the abbot of Nostre-Dame de Serrance is both a "vray hypocrite" and a miser. The narrator recounts his joy on hearing that the pilgrims will pay for the bridge, "car son avarice ne le permectoit." The abbot's portrait, uttered without irony, is the first hint of repeated criticism ofspecific clerical vices in the text.

Other ideologies are stated and reinforced not by the public narrator but by diverse characters, and here lies the problem of whether or not to assign them the status of dominant or subordinate authority. The public narrator establishes an atmosphere of equality among the storytellers, yet some degree of authority is given to Oisille, in view of her age, and to Parlamente. who sets the rules of the game. The reader assumes that the devisants share equal authority at the secondary level of narration. In the absence of a clearly-defined hierarchy, the only way the informed reader can judge the authority of a given ideology is to examine the degree to which it is reinforced.

Some values are reinforced by a group of characters sharing similar characteristics. Saffredent, Simontault, and Hircan denounce the hypocrisy of women who disguise their love and resist giving way to sincere affection. They set themselves in opposition to the concept of parfaite 
amitié, an ideology illustrated and praised by Parlamente and Dagoucin, and to a lesser extent, by Dame Oisille. The informed reader, familiar with the Queen of Navarre's concern for parfaite amitie in her other works, might be tempted to give authorial equivalence to the ideology of perfect love and subordinate the view of the opposition. But as the tales depicting the course of parfait amitie illustrate, the prevalence of the opposing view, pointing out the difficulty of following the tenets of perfect love, constantly undermine man or woman`s attempts to realize the ideal - a true spiritual union with God. As a consequence, the two camps and their views exist as conflicting forces. Neither the extrafictional voice nor the public narrator intervenes to resolve the dialogue. ${ }^{28}$

An area in which the views of the devisants tend to reinforce one another is in the depiction of male clerics. From the most pious, Oisille, to the least respectful, Hircan, their portraits of male clergy underscore the carnal passion of the individual clerics, their hypocrisy, and their abuse of the confessional role. To some extent, the genre demands a certain element of anticlericalism, and tales of monks seeking sexual pleasure with nuns and parishioners abound in the works of Philippe de Vigneulles and Bonaventure Des Périers. Yet the comments of the storytellers in the Heptaméron indicate a greater interest in the subject of clerical abuse than the genre demands. Either explicit or ironic comments on the tales themselves allow the storytellers to pinpoint the source of clerical abuse. Oisille blames the Franciscan emphasis on good works for the suicide of the young mother (Tale 23). Hircan mocks the incestuous mother who looks to the papal legate and "plusieurs docteurs en theologie" in Avignon to solve her problem (Tale 30). The devisants recount on a number of occasions the folly of those who put their trust in members of various spiritual orders instead of in the grace of God (Tales 5, 23, 31, 56, 72).

The unequivocal attack on clerical abuses by the storytellers as well as their failure to provide the promised tales highlighting clerical virtue leads the reader to grant authorial equivalence to the criticism expressed. One omission, the absence of criticism of nuns, with the exception of the ingenuous nun of Tale 72 , marks a departure from the tradition of the novella and perhaps indicates an effort on the part of the novel to protect a group that had suffered enough physical and verbal abuse. It is not surprising that the person speaking most eloquently for faith in God's grace should be Soeur Marie Heroet.

If there is controversy surrounding the comportment of men and women in marriage, there is at least a reinforced belief in human frailty. Even Hircan, whose concerns are more often material than spiritual, expresses the need to face one's weakness and to put one's faith in God:

Voylà, mes dames, comme il en prent à celles qui cuydent par leurs forces et 


\section{8 / Renaissance and Reformation}

vertu vaincre amour et nature avecy toutes les puissances que Dieu y a mises. Mais le meilleur seroit, congnoissant sa foiblesse, ne jouster poinct contre tel ennemy, et se retirer au vray Amy et luy dire avecy le Psalmiste:

"Seigneur, je souffre force, respondez pour moy!" (p.233)

It is rare that the views of Hircan and his wife Parlamente coincide, but her response to his words show her agreement: "Sçachez... que le premier pas que l'homme marche en la confiance de soy-mesmes, s'esloigne d'autant de la confiance de Dieu." This brief resolution of tension between two poles of feminine and masculine point of view invites the reader to grant authorial determinacy to what is textually defined as the Pauline view of human weakness (Tale 70, p.418).

Philippe de Lajarte warns us against trying to give an ideological reading of the Heptaméron. His judgment that the structure is dialogic - presenting contrasting ideologies rather than a single truth - is reinforced by the structure of the work itself, the opposition of tale and dialogue..$^{29}$ Yet the analysis of point of view reveals that the reader can locate limited areas of reinforced ideological stance or moments of coincidence to which he or she may attribute a degree of authorial determinacy. But on the specific topics of love, marriage, female and male roles in conjugal and extraconjugal relationships, the dialogue between devisants, especially between male and female storytellers, remains the vital and largely unresolved dynamic force in the Heptaméron.

Let us take up the final concern of the present study to tie together the three broad topics of point of view - status, contact, and stance: Is there a female voice in the Heptaméron? If we assume that unless there are marked signs to the contrary, the reader who has noted the presence of a female extrafictional voice will assign a female identity to the primary narrative voice, then from the outset of the prologue, the reader will assume the public narrator to be female. The narrative voice, however, takes such a posture of restraint that what comes through to the reader is a neutral presence - a neutral, genderless presence to mediate the polarity and tension that exists between storytellers.

We might compare the controlled posture of the Heptaméron's public narrator with the exuberance of the marked masculine voice of the public narrator in Des Périers's Nouvelles Récréations et Joyeux Devis. He first addresses what seems to be his privileged reader, "mon amy," to whom he assigns a masculine gender. ${ }^{30}$ His jurons, "ventre d'ung petit poysson! Rions!", suggest a lively dialogue between male companions. Only secondarily does he address the women among his inscribed readers, not "amyes," but "dames et demoyselles." Tongue in cheek, he suggests that they have their brothers and cousins read the text beforehand and mark the passages "trop gaillars" lest they fall upon them unawares. Or they can spin as the passages are read aloud and pretend not to listen. 
The jocular, good-natured presence of Des Périers's narrator, intent on maintaining constant contact with the narratee, in no way resembles Marguerite's public narrator but shares much in common with the language and posture of her secondary narrators. The prologue of the Heptaméron is not so much a dialogue as a narrative establishing distance between narrator and narratee. The sense of remoteness comes from the use of the historical past tense and the limited use of authorial selfreference. If the voice of the public narrator declines to assume a marked personality, the private narrators assume each one a distinctive character, and it is here that we find the female voice. While each voice is unique, the individual voices combine with their different tenors to create the voice of female experience, distinct from the male voice.

The novella as genre had inherited a tradition of denigrating feminine virtue in the manner of the Cent Nouvelles Nouvelles. While the Heptaméron includes tales depicting female inconstancy, its structure provides opportunity to present a different vision of the female experience. If there are adulterous wives, there are numerous examples of virtuous women, and men step forward to illustrate the courage of these women. Geburon's portrait of Soeur Marie Heroet, where he convincingly assumes her voice and perspective as she combats the assaults of a lecherous Benedictine, is only one example.

As the creative force behind the Heptaméron, Marguerite sets out not to hide female weakness any more than she tries to conceal masculine virtue, but because of her closer mimetic authority to the experience of the women she is depicting, she can give a voice to the fears, hopes, and disappointments of the female point of view.

If we accept the female authorship of the Contes amoureux of Jeanne Flore, Marguerite is one of the few female voices to recount nouvelles. ${ }^{31}$ It is to be expected that her voice would renew the genre, give it new form and new directions, particularly in the domain of psychological conflict as perceived through shift in focalization and voice. As Helene Cixous says in the Laugh of the Medusa, "A feminine text cannot fail to be more than subversive. It is volcanic; as it is written it brings about an upheaval of the old property crust, a carrier of masculine investments. There is no other way." 32

What the female voice offers in the Heptaméron is a glimpse of women's experience not shared by men. Elaine Showalter proposes a cultural model for the study of feminine writing. ${ }^{33}$ Men and women coexist in interlocking spheres, where the greater portion of the system represents shared experience of the dominant (male) and the muted (female) group. There exists a portion of both spheres which is not shared. In the Heptaméron, the zone of exclusively female experience, women's conscious or unconscious perceptions as she reacts in this zone, gains expression. The 
feminine voice in the Heptaméron relates and re-creates a woman's reaction to her husband's infidelity, her terror as she finds herself physically threatened, her desires and ideals as she enters a relationship. The reader in search of the woman in the textual voice will find it in this muted area muted because it found no voice in the works of Marguerite's male nouvellistes. In the process of renewing the genre, Marguerite de Navarre rediscovers woman's muted voice.

\section{Arizona State University}

Notes

1 The degree to which one acknowledges the equivalency between authorial voice and character can be seen in the introduction to Michel François's edition of the Heptameron: "Les recherches des critiques one permis l'identification certaine de la plupart des devisants parmi lesquels Oisille (Louise de Savoie), Dagoucin (Nicolas Dangu), Hircan (Henri d'Albret, le mari de Marguerite) et Marguerite elle-meme, sous le nom de Parlamente, ont une place A part" (Paris: Garnier Fréres, 1967), p. xii. All further references to the Heptaméron will be made to this edition. Other authors who have explored the identification of the devisants with members of the court of François I include: Pierre Jourda, Marguerite d'Angoulême, Duchesse d'alençon, Reine de Navarre (Paris: Honoré Champion, 1930), pp. 740-766; J. Palermo, "L'Historicité des devisants de l'Heptaméron Reconsidered," Revue d'Histoire littéraire de la France, 69 (1969), 193-202; and AJ. Krailsheimer, "The Heptameron Reconsidered," in The French Renaissance and Its Heritage, Essays Presented to Alan M. Boase, (London: Methuen and Co., Ltd., 1968), pp. 79-92.

2 In a work which has greatly influenced the development of the present study, Susan Sniader Lanser makes a distinction between diegetic authority, the authority attached to the authorial voice regarding reliability in reporting events in the fictional universe, and mimetic authority, authority that attaches to the acting persona, The Narrative Act: Point of View in Prose Fiction (Princeton University Press, 1981), p. 142. Private narrators, narrators who narrate to other characters within the body of the fictional universe, "might be said to enjoy varying degrees and proportions of diegetic and mimetic authority."

3 By reader, we refer not to the author's contemporaries, but to a construct "embodying al those predispositions necessary for a literary work to exercise its effect." See Wolfgang Iser, The Act of Reading: A Theory of Aesthetic Response (Johns Hopkins University Press, 1978), p. 54.

4 Mary Jacobus, “Is There a Woman in This Text?," New Literary History, 14 (1982), 117-141.

5 Lanser, The Narrative Act, pp.108-148.

6 The modern critical reader must look to the introductory pages of the François edition or seek out the individual editions housed in the Biliotheque Nationale to have access to these elements of the extrafictional voice.

7 The term "author" refers to a "textually encoded, historically authoritative voice, kin to but not identical with the biographical person who wrote the text" (Lanser, p. 152).

$8 \mathrm{Bal}$ has tried to clarify Genette's division between the primary (diegetic) and secondary (metadiegetic) narrative levels. See Genette, Figures III (Paris: Editions du Seuil, 1972), pp. 238242; Narrative Discourse: An Essay on Method, trans. Jane E. Lewin (Ithaca/London: Cornell University Press, 1980), pp. 227-234; Mieke Bal, "Narration et Focalisation: Pour une théorie des instances du récit," Poétique, 29 (1972), 107-127.

9 In showing the spectrum ranging from report to invention, Lanser states that she is referring to the referential claim rather than to absolute historicity. p. 164. The narrators, both public and private, are careful to add some geographical and historic details to increase the referential claim of events in the tales. While the genre would lead us to describe the tales as "fictive truth." the number of explicit references to events at court and specific members of the royal families of France and Italy encourage a classification closer to the pole of report than to the pole of pure invention (Lanser. pp. 163-164). 
10 Genette, Figures III, pp. 253-255; Narrative Discourse, pp. 243247.

11 Des Périers resorts to the dativus ethicus, the inclusion of the indirect object vous in narrating events which would ordinarily not require an indirect object, only to remind the reader of his or her involvement in the narrative act.

12 Genette, Figures III, p. 129; Narrative Discourse, pp. 95-96; Chatman, Story and Discourse: Narrative Structure in Fiction and Film (Ithaca: Cornell University Press, 1978), PP. 222-223.

13 Lanser cites Boris Uspenskii's use of polyphony to describe an ideology reinforced by multiple voices in a text (Lanser, p. 220); Boris Uspenskii, Poetics of Composition: The Structure of the Artistic Text and Typology of Compositional Form, trans. Valentin Zavarin and Susan Wittig (Berkeley: University of California Press, 1973).

14 I cite two explicit references to the positive power of narration:

Voylà, mes dames, une histoire que voluntiers je vous monstre icy pour exemple, à fin que quand vos mariz vous donnen des cornes de chevreux, vous leur en donne'z de cerf. (LHeplaméron, p. 27)

Mes dames, je croys que aprés avoir entendu cesle hisloire tres verilable, il niy a aucunes de vous yui ne pense deux fois à loger telz pelerins en sa maison.... (L'Heptaméron, p. 192)

15 See Gerald Prince, "Introduction a l"etude du narrataire," Poetique, 14 (1973), 178-186; "Notes toward a Characterization of Fictional Narratees," Genre, 4, 1 (1971), 100-106; and Mary Ann Piwowarczyk. "The Narratee in Selected Fictional Works of Diderot," Diss. University of Wisconsin 1978, pp. 33-34. Lanser creates a schema based on the work of Prince and Piwowarczyk (The Narrative Act, pp. 180-181). The degree zero narratee is "without any particularizing social, personal, or physiological characteristics which determine his/her identity"; "a participant in the situation of en unciation whose status and spatial-temporal are undefined"; and "a passive reader-listener whose presence is underemphasized."

16 Uspenskii, The Poetics of Composition.

17 Genette, Figures III, pp. 183-202; Narrative Discourse, pp.161-211.

18 Lanser, The Narrative Act, p. 187.

19 Deborah N. Losse, "The Representation of Discourse in the Renaissance Nouvelle," Poetics Today, 5 (1984), 584-595.

20 In psychonarration, the words of the character infiltrate to some extent the narrator's speech. See Dorrit Cohn, Transparent Minds: Narrative Modes for Presenting Consciousness in Fiction (Princeton: Princeton University Press, 1978), p. 11, p. 26. See also Lanser, The Narrative Act, p. 188. In the Nouvelles Récreations et Joyeux Devis, the narrative voice is reluctant to give up mediation and does so not in the interest of re-creating psychological struggle but to bring to life dynamic and witty verbal exchanges between characters.

21 Cohn, Transparent Minds, p. 29.

22 Borrowing the terms "panorama" or "survey" from Percy Lubbock to describe the pole of open survey, Lanser places a "fixed intrapersonal ordination of a single character" at the opposite pole, entitled "fixed concurrence." Free ordination and shifting ordination occupy the midpoint (Lanser, The Narrative Act, pp. 192-198). See also Percy Lubbock, The Craft of Fiction, (New York: Viking Press, 1957).

23 For a discussion of scene versus summary, see Genette, Figures III, pp. 122-124; Narrative Discourse, pp. 86-88, Chatman, Story and Discourse, pp. 72-74. Lanser, The Narrative Act, pp. 200-201.

24 Lanser, The Narrative Act, pp. 202-215.

25 See Genette, Figures III, pp. 207-08; Narrative Discourse, pp. 189-190.

26 Tzvetan Todorov, Les Genres du discours (Paris: Editions du Seuil, 1978), p.91.

27 Todorov, Les Genres du discours, p. 91.

28 While showing how Marguerite de Navarre's concept of Neoplatonism differs from Ficino's Neoplatonism, Philippe de Lajarte draws the following conclusions: "L'Heptaméron ne nous présente pas de doctrine de l'amour une et cohérente: il donneplutot, au sujet de l'amour, occasion de s'affronter à deux philosophies opposees de la nature humaine: l'une "optimiste" (c'est 


\section{2 / Renaissance and Reformation}

le ficinisme), l'autre "pessimiste" (c'est, disons, la doctrine la plus proche de l'orthodoxie chrétienne, encore que manifestement teintes de protestantisme). La coexistence et le "dialogus" de ces deux idéologies antagonistes sont déjà en eux-mêmes des faits significatifs," "LHeptaméron et le ficinisme: rapports d'un texte et d'une idéologie," Revue des Sciences Humaines, 37 (1972) 339-371. Lajarte points out that Dagoucin's concept of love, with its emphasis on perfection in the male differs from Parlamente's view, where the spiritual end is of prime importance.

Since the writing of the present study, the excellent article by Philippe de Lajarte has come to my attention: "Le Prologue de L'Heptaméron et le processus de production de l'oeuvre," in La Nouvelle français à la Renaissance (Genève/Paris: Editions Slatkine, 1981), 397-423. He contrasts the monologic discourse of the primary narrator, a single, absolute voice, with the dialogic discourse of the secondary narrators, where diverse opinions are expressed and tolerated.

29 Lajarte, "L'Heptaméron et le ficinisme," p. 370.

30 Bonaventure des Périers, Les Nouvelles Récreations et Joyeux Devis, in Conteurs français du seizieme siecle, ed. Pierre Jourda (Paris: Gallimard, 1956), p. 368.

31 Gabriel-A. Perouse, in Nouvelles françaises du XVIe siècle. Images de la vie du temps, Travaux d'Humanisme et Renaissance CLIV (Geneva: Droz, 1977), asserts: "C'est l'ouvrage d'une "jeune femme née dans la bourgeoisie aisee, en France à laurore du regne de François Ier," p.87.

32 Hélène Cixous, "The Laugh of the Medusa," trans: Keith Cohen ánd Paula Cohen, Signs, 1 (1976), 875-893. The potential subversiveness of Marguerite's text can be seen in Claude Gruget's efforts to remove those passages which he feared might incite the ire of the board of censors at the Sorbonne.

33 Elaine Showalter, "Feminist Criticism in the Wilderness," Critical Inquiry, 8 (1981), 179-205. Showalter applies the anthropological model of female culture proposed by Shirley and Edwin Ardener, "Belief and the Problem of Women," in Perceiving Women, ed. Shirley Ardener (New York: John Wiley, 1975). p.3. 